\title{
Extensive subcutaneous emphysema due to failed endotracheal intubation with vallecular rupture
}

\author{
Carlos Felipe Matute Martinez (i), ${ }^{1}$ Catherine Wiechmann, ${ }^{2}$ \\ Alexander Bastidas-Palacios ${ }^{3}$
}

${ }^{1}$ Internal Medicine, Texas Tech University Health Sciences Center School of Medicine, Odessa, Texas, USA ${ }^{2}$ Texas Tech University Health Sciences Center School of Medicine Permian Basin, Odessa, Texas, USA ${ }^{3}$ Intensive Care Unit, Medical Center Hospital, Odessa, Texas, USA

\section{Correspondence to} Dr Carlos Felipe Matute Martinez;

carlosfmatute@gmail.com

Accepted 4 May 2021

Check for updates

(c) BMJ Publishing Group Limited 2021. No commercial re-use. See rights and permissions. Published by BMJ.

To cite: Matute Martinez $\mathrm{CF}_{\text {, }}$ Wiechmann C,

Bastidas-Palacios A. BMJ

Case Rep 2021;14:e237377.

doi:10.1136/bcr-2020-

237377

\section{DESCRIPTION}

Vallecular rupture is a rare but potentially lifethreatening condition that could have deleterious outcome due to upper airway and jugular venous compression. Postintubation airway rupture (PiAR) is a rare condition being tracheal rupture associated with emergent endotracheal intubation (EEI) the most common type with a prevalence less than $0.37 \%$ in general population. ${ }^{2}$ Vallecular rupture is very uncommon. Its prevalence associated with subcutaneous emphysema preceded by EEI is unknown. PiAR is characterised by inadvertent airflow into the surrounding soft tissue, which may extend to the head, neck, intra/extra thoracic, abdomen and extremities. Subcutaneous emphysema is a predominant clinical feature. ${ }^{1-3}$

An 84-year-old woman with a history of congestive heart failure, coronary artery disease and longstanding persistent atrial fibrillation was transferred from an outside facility with a history of failed tracheal intubation after an episode of syncope preceded by a brief episode of severe shortness of breath. On arrival to the emergency department, the patient was unresponsive and ventilated through laryngeal mask.

Physical examination depicted palpable cutaneous crepitus compatible with extensive subcutaneous emphysema extending from bilateral upper thighs to the head. This was associated with nonpitting oedema. Emphysema was confirmed with portable chest X-ray film (figure 1). She was tachypnoeic with oxygen saturation of $96 \%$. Otorhinolaryngology was consulted for suspected upper airway rupture and airway stabilization. The patient was taken to the operating room and direct laryngoscopy revealed a laceration on the left vallecula. Bronchoscopy was unremarkable; a tracheotomy was done without complications. Subcutaneous emphysema resolved completely 1 week after the tracheostomy, but the patient died from complications related to her underlying comorbidities.

Oropharyngeal lacerations are well known yet rare complication of emergent and traumatic endotracheal intubation. ${ }^{3}$ Iatrogenic vallecular perforation is a serious but fortunately very uncommon complication. $^{4}$

Initial diagnosis of PiAR is based on a strong clinical suspicion. Traditionally, aerodigestive tract lesions have been associated with acute haemoptysis and new onset massive emphysema. ${ }^{4}$ The presence of subcutaneous emphysema favours early diagnosis and initiation of appropriate treatment. $^{12}$ This should always warrant a prompt

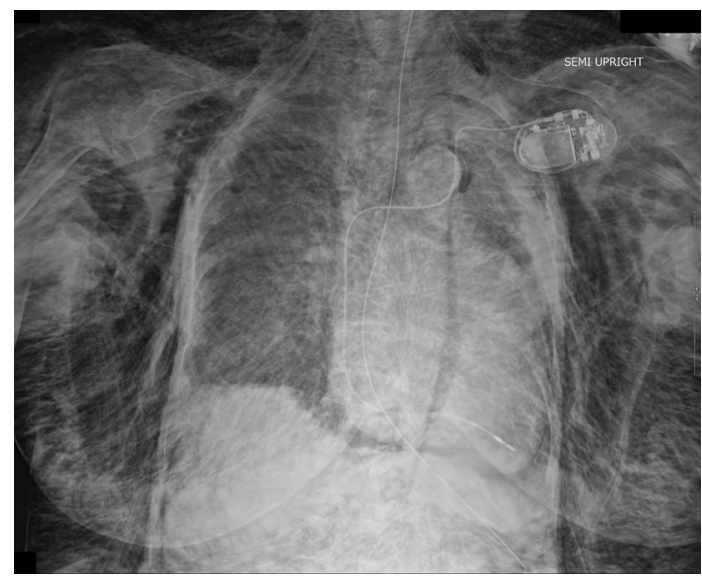

Figure 1 Portable chest X-ray film showing severe diffuse subcutaneous emphysema.

fiberoptic laryngoscopic and bronchoscopic examination. ${ }^{14}$

Postintubation vallecular rupture is thought to be secondary to anterior laryngoscope stylet traction with inappropriate force over the vallecular portion of the oropharynx during upper airway exploration. On the other hand, tracheal ruptures are associated with the use of oversized probes, less firm or weaker pars membranosa. The latter more commonly seen in women. ${ }^{12}$ Chronic steroid therapy increases tissue fragility and has been identified as a possible predisposing factor. Other risk factors include poor visualisation of the true vocal cords, trismus, macroglossia, blood, secretions and relatively inexperienced personnel.

The treatment of choice mainly depends on the location, extension and severity of the lesion as well as the risk of airway collapse. It is therefore of paramount importance to secure the airway. Extensive

\section{Learning points}

- Vallecular rupture after emergent endotracheal intubation is thought to be secondary to anterior laryngoscope stylet traction.

- The predominant signs and symptoms of postintubation airway rupture are subcutaneous emphysema, respiratory insufficiency and diffuse extensive pneumothorax in the context of failed emergent endotracheal intubation.

- Diagnostic confirmation of airway rupture is made by laryngoscopy and bronchoscopy. 
subcutaneous emphysema secondary to oropharyngeal lesions is generally managed with tracheotomy to bypass the site of injury and secure the airway. Tracheal rupture has traditionally been managed with urgent surgical repair. Ideal treatment approach remains unclear, although conservative management has been associated with better outcomes. ${ }^{1}$

Clinicians should be aware of complications of PiAR. Rapid identification of vallecular and tracheal lesions is associated with improved outcomes. ${ }^{12}$ In our patient, early identification of the vallecular lesion allowed the clinicians to promptly secure the airway and address the underlying pathologies that led to endotracheal intubation.

Contributors CFMM contributed in all the parts of the manuscript, including planning, design, data collection, analysis of data, drafting and revision. CW contributed in data collection, analysis of data, drafting and revision. AB-P contributed in drafting and revision.

Funding The authors have not declared a specific grant for this research from any funding agency in the public, commercial or not-for-profit sectors.
Disclaimer Case reports provide a valuable learning resource for the scientific community and can indicate areas of interest for future research. They should not be used in isolation to guide treatment choices or public health policy.

Competing interests None declared.

Patient consent for publication Next of kin consent obtained.

Provenance and peer review Not commissioned; externally peer reviewed.

ORCID iD

Carlos Felipe Matute Martinez http://orcid.org/0000-0002-5174-1349

\section{REFERENCES}

1 Miñambres E, Burón J, Ballesteros MA, et al. Tracheal rupture after endotracheal intubation: a literature systematic review. Eur J Cardiothorac Surg 2009;35:1056-62.

2 Schaeffer C, Galas T, Teruzzi B, et al. latrogenic Tracheal Rupture Caused by Emergency Intubation: A Case Report. J Emerg Med 2018;55:e15-18.

3 Postma GN, Buenting JE, Jones KR. Oropharyngeal perforation after traumatic intubation. Otolaryngol Head Neck Surg 1995;113:290-2.

4 Kwon JK, Lee SR, Lee HM, et al. Vallecular rupture with cervical spine fracture after a failed hanging suicide attempt. Am J Forensic Med Pathol 2013;34:205-6.

Copyright 2021 BMJ Publishing Group. All rights reserved. For permission to reuse any of this content visit https://www.bmi.com/company/products-services/rights-and-licensing/permissions/

BMJ Case Report Fellows may re-use this article for personal use and teaching without any further permission.

Become a Fellow of BMJ Case Reports today and you can:

- Submit as many cases as you like

- Enjoy fast sympathetic peer review and rapid publication of accepted articles

- Access all the published articles

- Re-use any of the published material for personal use and teaching without further permission

Customer Service

If you have any further queries about your subscription, please contact our customer services team on +44 (0) 2071111105 or via email at support@bmj.com.

Visit casereports.bmj.com for more articles like this and to become a Fellow 